\title{
HEALTH AND ILLNESS IN THE RUSSIAN CONTEXT: SOME SOCIO-PSYCHOLOGICAL COMMENTS
}

\author{
I.B. Bovina, N.V. Dvoryanchikov, S.Yu. Gayamova \\ Moscow State University of Psychology and Education \\ Sretenka, 29, Moscow, Russia, 127051 \\ L. Dany, M.-A. Aim \\ Aix-Marseille University \\ Avenue R. Schuman, 3-29, Aix-en-Provence, France, 13628
}

\begin{abstract}
The aim of the presented article is to discuss some aspects of the cultural and social contexts of health and illness, to reveal the particularities that differentiate the understanding of health and illness kept by Russian people from other people. The special attention is paid to the particularity of the image of the world based on the Russian language. It was underlined that the Russian language provided the speaker with a wide range of opportunities to withdraw the responsibility for own actions. The analysis of health and illness particularities in the Russian language proposed by Kolesov, Fasmer is discussed in relation to the social representations and its formation. The analysis of the social context of health and illness refers to the socio-economic factors and the demographic facts, the neglect of health as one of the main feature of the social practice related to health and illness is discussed.
\end{abstract}

Key words: health, illness, social representations, culture and social contexts, the unpredictability of the world

\section{Introduction}

The rich potential of the social representations theory to study the health and illness issues has been explicitly shown in the numerous studies (Bovina, 2007, Emelyanova, 2016, Flick, 2002, Galli \& Fasanelli, 1995; Jodelet, 1989, Jovchelovitch \& Gervais, 1999) realised in different cultural contexts after the pioneering works by Moscovici (1961) and Herzlich (1973); the notion of utility of this theory for the further analysis of such complex objects as health and illness has been once again in the focus of the recent scientific discussions (Jodelet, 2016).

However, some last results on the social representations of health (Aim, Decarsin, Bovina \& Dany, 2016) made it crucial to do a deeper analysis of the methodological aspects of the research on the social representations of health.

Another aspect of the health and illness issue that should not be disregarded is related to the cultural and social contexts that influence the social representations and determine the social practice towards health and illness. Consequently, the aim of the presented article is to discuss some aspects of the cultural and social contexts of health and illness, to reveal the particularities that characterise the understanding of health and illness kept 
by Russian people. In other words, the main interest here is to analyse the cultural and social contexts that influence the social representations of health and illness. It should be pointed out that the comparison of social representations of health and illness in different cultural contexts is not a part of our interest in here.

By analysing Russian language Wierzbicka (Zaliznyak, Levontina \& Shmelev, 2012) underlines its fundamental characteristics as emotionality, irrationality, absolutization of morality (that can be explained as a kind of preoccupation with the moral dimension, the enthusiasm to make moral judgements, the use the morality as the main dimension for judgements in different spheres of life). Another important characteristic of the Russian language is passivity, inaction; Wierzbicka describes it in the following manner: " ... the feeling that the human beings are not in control of their lives and their control over events is limited; a tendency to fatalism, resignation, submissiveness" (Zaliznyak, Levontina \& Shmelev, 2012, p. 189).

Following these ideas proposed by Wierzbicka, Zaliznyak with colleagues show that the Russian language provides the speaker with a wide range of opportunities to withdraw the responsibility for own actions (Zaliznyak et al., 2012). This particularity of the Russian language corresponds to one of the key ideas that form the image of the world in the language, namely - the unpredictability of the world. One can easily imagine that as a result, this unpredictability affects the behaviour and the strategies that individuals use in order to act towards the reality. This particularity is pertinent to the context of the health and illness issues, as far as the way of explanation of reality predicts the intention to take or not to take any actions.

\section{Cultural context}

In order to reveal the particularities of health and illness in the Russian cultural context one should have a closer look at the etymology of these words. The word "health" has the same roots with the word "tree" (dorvz), initially, the word that was used su-dorv-o ${ }^{1}$, (it means to be strong as a tree) (Fasmer, 2004).

At the Middle Ages meaning of health referred to tree, robustness and strength. Being healthy meant being strong, sturdy like a tree (Kolesov, 2000). In the other Slavic languages one finds the same references to the tree (in particular in Polish, Belarusian and Czech languages) (Mokienko, 2005).

According to the dictionary of Russian dialects, there are more than 200 words that have common roots with the word "tree". The history of Slavic culture can be explained through these words.

The health was seen as an external characteristic, not belonging to individual, it can be given or presented to another person, as underlines Kolesov (2000) by referring to the Hypatian Codex. It was a characteristic of the individual as a member of the community, and therefore could be analyzed only as a phenomenon within the framework of "individual-community" relationships.

The individual was not responsible for his or her own health because the responsibility was shared among the members of the group, and collective action was required to heal the individual. It was necessary to wish a robust health to the individual to cure him, and

$1 *_{s z d o r v z}-s u$ «good» and dorvo - tree, literally - “(made) from good tree” (Fasmer, 2004). 
in healing the individual regaining his strength (Kolesov, 2000).This action of wishing good health to others has remained in the Russian language and is accomplished every day when one says "Hello" (Zdravstvuite), "Salut" (Zdorovo), the military greeting is literally a health wish (Zdraviya zhelau). Some other phrases are also used in everyday situations, for example, the expression na zdorov'e (health) is used as an answer to the gratitude of another person; the expression za zdorov'e (for health) is used in case of drinking toast. The stereotyped form of greeting contains the wishes of strong health.

According to the last edition of «Russian associative dictionary», the most frequent words that associate with health are strong and good (Karaulov et al., 2002). The connotation of strength is still presented.

As shows the analysis proposed by Kolesov (2000), at the Middle Ages the word «illness» did not exist in the Russian language; but, of course, it does not mean that individual did not suffer from different illnesses. Illness "is the most common and dramatic event of life" (Nikolaeva, 1995, p. 207). The whole history of mankind can be represented through the history of illnesses, the fight against illnesses or the search of the ways to improve the quality of life (Nikolaeva, 1995).

This absence of the word is explained by the fact that the same word was used to refer to misfortune and its reason, so by naming misfortune one can provoke it. As a result, the word that corresponded to illness or that signified this state was under taboo. The belief in the magic power of words was very widespread at that time, and it explains the absence of the word "illness". According to the medieval man thinking an ill person needed to get some strength in order to recover from his illness. The verb that was used to define what happened with the ill person - boleet - meant that the individual accumulated the strength, accumulated health, a person himself was called bol' (pain). This meaning of strength remained in the Russian language until now in certain words such as bol'shoi (big), bol'she (bigger).

Two words appeared in the $9^{\text {th }}$ century in order to indicate illness: nemosch' (inability) nedoug (infirmity). The roots of these words refer to strength, the prefix ne-indicates a reduction of strength, but not the total absence of it. Such vision of illness refers to actions to cure, it makes useful the shaman's help who heals illnesses, gives strength to an ill person, so individual has not a reduced strength, but the whole one (Kolesov, 2000).

In the codex of Prince Vladimir (dated by 966) there was a note concerning bathhouse (it named as an establishment for ills, or nemoguschikh (not able) (Sergeeva, 2005). In the Russian culture, bathhouse represents the way to treat the ill people and to improve the state of healthy ones. The bathhouse was always wooden, the birch broom was used for the construction. The meaning of wood, especially of birch, in relation to health and illness is reflected in the proverbs.

As Kolesov (2000) shows, the transformation of the meaning of illness happened in $10^{\text {th }}$ century. At first, being ill meant to receive strength, then being ill meant to have less strength, finally, being ill meant to suffer from physical pain, the individual who suffered from illness was weak, he had no strength at all. This last explication of illness implicates the necessity of the other ways of treatment than the shaman's healing.

The word "illness" was used at first by the scribers in Kiev, and this word circulated in this groups of people. This word became the one to indicate suffering, pain, only after 
three centuries of the Tatars' invasion, the experience of pain and suffering (Kolesov, 2000). Historically speaking, the words used to indicate illness were: pain - infirmity inability - illness; only from the $15^{\text {th }}$ century the word "illness" was used as a more general concept among the other concepts of this list (Kolesov, 2000).

A reconstruction of the representations kept by Russian people about illness based on the analysis of the Russian language and on the demographic sources shows that they were not changed a lot since the Middle Ages till the $19^{\text {th }}$ century (Andreev et al., 2006). This allows us to think that the image of illness kept by Russian people at the end of the $19^{\text {th }}$ century was quite different from the one in the other cultures.

In the last edition of Russian associative dictionary the most frequent words that associate with illness are severe (illness) and (illness) of the century (Karaulov et al., 2002). These associations probably reflect the extremity of judgements that characterise the Russian mentality.

Thus, the idea of strength is fundamental to explain health and illness in the Russian culture. In the psychosemantic analysis of health proposed by Vasil'eva and Filatov (2005), it was found that strength was an important element of the representation on health (the three factors were identified: namely, adaptation, inner consistency and self-realisation. Each factor had its own content, strength was found in the first factor - adaptation together with such elements as norm or adequacy, performance, attractiveness, sociability, material wealth, family happiness etc.). In two studies realised among young Russians there was shown the importance of strength and weakness as the key elements to form the social representations of health and illness (Bovina, 2007), whereas, in the studies realised by the French and Italian colleagues, the social representations of health and illness are crystallised around the elements activity - inactivity (Galli \& Fasanelli, 1995, Herzlich, 1973).

However, the further research (in a larger sample from children to elder people) is needed in order to answer the question about the themata (Moscovici, 2001) that generate the social representations of health and illness in the Russian culture.

The reconstruction of health and illness based on the analysis of the Russian language allows Kolesov (2000) to conclude that illness and health were perceived as two coasts of a river, they exist at the same time and they are opposed one to another in the same manner as two riversides, but still they are the parts of the river.

It should be also mentioned that the impersonal sentences ${ }^{1}$ are frequently used to express the reasons of illness. This kind of sentences is difficult to translate into other languages (Kolesov, 2004).

\section{Social context}

The analysis of the sociological literature (Gordon et al., 1998) gives us a possibility to conclude that the Russian history is a perfect example of the neglect towards life and health of individual, because the life of a person was subordinated to the interests of community or the society; as a result the individual neglected his own health, did not

1 The different kinds of impersonal sentences reflect the representation of «shaky external world»; it is a feature of the Russian mentality (Kolesov, 2004). 
take care of it (it is important to mention that health was an individual value in the Western society, it applied the responsibility for the care about one's health).

The cultural roots of this phenomenon were analysed in the previous paragraph, here we will have a look at the social context related to health and illness.

The analysis proposed by A.G. Vishnevsky with colleagues (Andreev et al., 2006) concerning the end of the $19^{\text {th }}$ - the beginning of the $20^{\text {th }}$ century reveals the existence of the archaic system of illnesses and mortality determined by the socio-economic conditions of living. The vision of illnesses and its prevention by the peasant majority was not different from the one shared in the medieval period. Illnesses were seen as a punishment for sins, as a result, they should be experienced submissively, and a prayer was used as a measure to experience the illness.

The sanitary measures were considered by peasant population as one of the main ways of contamination, but in reality, the living conditions were very poor and they were favouring to contamination.

At the end of the $19^{\text {th }}$ century, the inhabitants of whole villages suffered from syphilis that was transmitted from one family member to another, from neighbour to another, from people from one village to people from another etc. The spread of the illness happened during the mass celebrations (Privalova, 2000). In this case, the illness transmission rather indicates the living conditions of the peasant population, than the modes of sexual behaviour ${ }^{1}$.

The efficacy of governmental ideas to control and to isolate people suffering from different illnesses at the end of $19^{\text {th }}$ - beginning of the $20^{\text {th }}$ centuries was criticised by doctors; they argued that the fear of the obligatory treatment would lead to the concealment of the illness and to the further spread of the illness.

The level of mortality from the infectious diseases (like smallpox, measles, whoopingcough, and typhoid fever) were several times higher in Russia at that time than in the European countries (Andreev et al., 2006).

The individual sense of self-preservation was not developed, as a result individual had a passive attitude towards death, and especially it was presented in the case of the infant mortality. And this passivity was not determined by the socio-economic factors - since the $15^{\text {th }}$ century as the demographists say the amount of children in that had a married woman from the peasant family was from 8 to 10 (on the average).

This passivity is also explained by the cultural factors. So the social context relates on the cultural one. The proverbs express this passivity: These children will die, the new children will be born, God gives (children) and God takes (Dal', 1994). One can noticed that the God as an explicative reason associated with health and illness issue was quite presented in the image of illness held people in Europe at the time of Middle Ages (Herzlich \& Pierret, 1987), especially, during the plague epidemic, but in the Russian situation this kind of reasoning was applied till the beginning of the $20^{\text {th }}$ century. It indicates the important gap of the world view in Russian context and European one.

First of all, the passivity towards death was a cultural feature. For the religious reasons death was not seen as the end, it was rather interpreted as a transition into another world.

${ }^{1}$ Syphilis is an illness of domestic life as it was underlined at the 1st congress of the Pirogov's society in 1885 . The peasants were not aware of the illness and the ways of transmission, they were not worrying about the suddenly arising rash (Privalova, 2000). 
This fundamental part of the culture cannot be changed overnight. Then, it reflects the powerlessness to change something, as a result, it is related to fatalism. Thus, this social context determines the social practice towards health and illness that was used in the everyday life.

On the one hand, more than a century has been passed since the time that was analysed above, some important transformations of the social context have happened. Living conditions have been changed, relations towards health and illness have been evolved. But are the modern individuals aware of health as a personal value? Do they take care of their health? Is the neglect towards own health disappeared?

On the other hand, the modernization of mortality that started at the beginning of the $20^{\text {th }}$ century was interrupted by the world wars and revolution, the further changes happened in quite different conditions. Enormous human losses of the $20^{\text {th }}$ century (related mainly to the revolutions, world and civil wars, and political repressions) has not only changed the demographic picture of the country but definitely influenced on the system of values, the importance of human life and health. Therefore, the tradition to neglect human life and health continues in the $20^{\text {th }}$ century.

In the recent analysis of the psychological state of society A.V. Yurevich (2014) demonstrates that the individuals in the modern Russian society do not take care of own health, he argues that not only socio-economic factors but the psychological state of society contributes into the growth of alcohol and drug consumption.

Another alarming feature of the modern situation is the level of suicide, especially among young people (Russia occupies one of the leading positions in the world) (Dvoryanchikov et al., 2014).

Only these two facts allow thinking that the relations between individual and society are not in favour of an individual, and his health does not occupy the highest position in the value system.

\section{Conclusion}

Our starting point was concerned with the potential and importance of social representations theory for the research on health and illness, these complex phenomena that have numerous dimensions of analysis. Despite the fact that health and illness in general and different illnesses were in the focus of analysis realised by researchers on social representations, some new questions appeared and the further lines of reflections have been indicated.

The main idea of our discussion in the article was related to the cultural and social contexts that influenced the social representations of health and illness and determined the social practice towards health and illness.

In general, the main characteristics of the Russian language are: emotionality, irrationality, absolutization of morality and passivity or inaction (Zaliznyak et al., 2012). Such a key category as passivity or inaction rooted in the language relates to some «fatalism, resignation, and submissiveness» (Zaliznyak et al., 2012, p. 189) as a basis of the behaviour towards the reality. As far as one of the key ideas that form the image of the world in the language, is the unpredictability of the world. Individuals have to handle with the reality in particular way and the domain on health and illness is not an exception of this unpredictability. 
The etymological analysis of the words health and illness provided us with a basis for hypothesis regarding the themata that generate the social representations of health and illness in the Russian culture.

The whole Russian history provides us with clear examples of the neglect towards life and health of individual, as far as the life of a person was subordinated to the interests of community or the society. As a result the individual neglected his own health, did not take care of it. The facts obtained in the current studies (Yurevich, 2014) still confirm the presence of the neglect that characterises the social practice related to health and illness.

\section{Acknowledgements:}

This article is a part of the research project supported by RGNF (16-26-08001 a) and FMSH.

\section{REFERENCES}

Aim, M.-A., Decarsin, T., Bovina, I. \& Dany, L. (2016). Représentations sociales et santé: penser le lien entre objet et méthodes. Paper presented at the $13^{\text {th }}$ International Conference on Social Representations, Marseille, France, 14-17 September 2016.

Andreev, E.M., Vishnevskiy, A.G., Zakharov, S.V., Sakevich, V.I. \& Kharkova, T.L. (2006) Ot kakogo berega my otchalili. In A.G. Vishnesky (Ed.), Demograficheskaya modernizatsiya Rossii 1900-2000 (15-64). Moscow: Novoe izdatel'stvo. (In Russ.).

Bovina, I.B. (2008). Sotsial'naya psikhologiya zdorov'ya i bolezni. Moscow: Aspekt press.

Dal', V.I. (1994). Tolkovyy slovar' zhivogo velikorusskogo yazyka. Moscow: Progress-univers. (In Russ.).

Dvoryanchikov, N.V., Bovina, I.B., Vikhristuck, O., Berezina, E.B., Bannikov, G. \& Konopleva, I.N. (2014). Self-murder and self-murderers in social representations of young Russians: An exploratory study. Psichologija, 50, 33-48. Retrieved from http://www.journals.vu.lt/psichologija/article/ view/4889

Emel'yanova, T.P. (2016). Sotsial'nye predstavleniya: istoriya, teoriya i empiricheskie issledovaniya. Moscow: Kogito-tsentr. (In Russ.).

Fasmer, M. (2004). Etimologicheskiy slovar' russkogo yazyka. Moscow: Astrel'.

Flick, U. (2000). Qualitative inquiries into social representations of health. Journal of health psychology, 315-324. doi: $10.1177 / 135910530000500303$

Galli, I. \& Fasanelli, R. (1995). Health and illness: a contribution to the research in the field of social representations. Papers on social representations, $1-13$.

Gordon, L.A., Voz'mitel', A.A., Zhuravleva, I.V., Klopov, E.V., Rimashevskaya, N.M. \& Yadov, V.A. (1998). Sotsiologiya byta, zdorov'ya i obraza zhizni naseleniya. In V.A. Yadov (Ed.) Sotsiologiya $v$ Rossii (432-453). Moscow : Institut Sotsiologii RAN. (In Russ.).

Herzlich, C. (1973). Health and illness: a social psychological analysis. London: Academic press.

Herzlich, C. \& Pierret J. (1987). Illness and society. Baltimore, London: John Hopkins University Press.

Jodelet, D. (1989). Folies et représentations sociales. Paris: Presses Universitaires de France.

Jodelet, D. (2016). Applications of social representations to education and health. Conference Tribute to Serge Moscovici, Paris, France, 17-18 September 2016.

Jovchelovitch, S. \& Gervais, M.-C. (1999). Social representations of health and illness: the case of the Chinese community in England. Journal of community and applied psychology, 247-260. 
Karaulov, Yu.A., Cherkasova, G.A., Ufimtseva, N.V., Sorokin, Yu.A. \& Tarasov, E.F. (2002). Russkiy assotsiativnyy slovar'. Moscow: Astrel'. (In Russ.).

Kolesov, V.V. (2000). Drevnyaya Rus': nasledie v slove. Mir cheloveka. Saint-Petersburg: Filologicheskiy fakul'tet Sankt-Peterburgskogo universiteta. (In Russ.).

Kolesov, V.V. (2004). Yazyk i mental'nost'. Saint-Petersburg: Peterburgskoe vostokovedenie. (In Russ.).

Mokienko, V.M. (2005). Vglub' pogovorki. Saint-Petersburg: Azbuka-klassika.

Moscovici, S. (1961). La Psychanalyse: son image et son public. Paris: Presses Universitaires de France.

Moscovici, S. (2001). Why a theory of social representations? In K. Deaux, \& G. Philogène (Eds.). Representations of the social: bridging theoretical traditions (18-61). Oxford: Blackwell Publishers.

Nikolaeva, V.V. (1995). Lichnost' v usloviyakh khronicheskogo somaticheskogo zabolevaniya. In E.T. Sokolova \& V.V. Nikolaeva (Eds.) Osobennosti lichnosti pri pogranichnykh rasstroystvakh $i$ somaticheskikh zabolevaniyakh (205-267). Moscow: SvR-Argus. (In Russ.).

Privalova, T.V. (2000). Byt rossiyskoy derevni 60 gg. XIX veka - 20gg. XX. Moscow. (In Russ.).

Sergeeva, A.V. (2000). Russkie. Stereotipy povedeniya, traditsii, mental'nost'. Moscow: Flinta-Nauka. (In Russ.).

Vasil'eva, O.S. \& Filatov, F.R. (2005). Psikhologiya zdorov'ya cheloveka. Fenomen zdorov'ya v kul'ture, psikhologicheskoy nauke i obydennom soznanii. Rostov-na-Donu: Mini Tayp. (In Russ.).

Yurevich, A.V. (2014). Psikhologiya sotsial'nykh yavleniy. Moscow: Institut psikhologii RAN. (In Russ.). Zaliznyak, A.A., Levontina, I.B. \& Shmelev, A.D. (2012). Konstanty i peremeennye russkoy yazykovoy kartiny mira. Moscow: Yazyki slavyanskikh kul'tur. (In Russ.).

(C) I.B. Bovina, N.V. Dvoryanchikov, S.Yu. Gayamova, L. Dany, M.-A. Aim, 2017

\author{
Article history: \\ Received 5 December 2016 \\ Accepted 17 January 2017 \\ For citation: \\ Bovina I.B., Dvoryanchikov N.V., Gayamova S.Yu., Dany L., \& Aim M.-A. (2017). Health and \\ illness in the Russian context: Some socio-psychological comments. RUDN Journal of Psychology \\ and Pedagogics, 14 (1), 7-16.
}

\title{
Bio Note:
}

Inna B. Bovina - Research director, Ph.D. in psychology, associate professor, professor of Clinical and Legal Psychology Chair, Moscow State University on Psychology and Education (Moscow, Russia).Contact information: e-mail: innabovina@yandex.ru

Nikolay V. Dvoryanchikov - Ph.D. in psychology, associate professor, professor of Clinical and Legal psychology Chair, Dean of Faculty of Forensic Psychology, Moscow State University on Psychology and Education (Moscow, Russia). Contact information: e-mail: dvorian@gmail.com

Svetlana Yu. Gayamova - Ph.D. in psychology, associate professor, associate professor of Forensic Psychology and Law Chair, Moscow State University on Psychology and Education (Moscow, Russia). Contact information: e-mail: sgayamova@yandex.ru

Lionel Dany - Research Director, Professor, Laboratory of Social Psychology, University of AixMarseille (Aix-en-Provence, France).Contact information: e-mail: lionel.dany@univ-amu.fr Marie-Anastasie Aim - PhD student, Laboratory of Social Psychology, University of Aix-Marseille (Aix-en-Provence, France). Contact information: e-mail: marie-anastasie.aim@univ-amu.fr 


\title{
ЗДОРОВЬЕ И БОЛЕЗНЬ В РУССКОМ КОНТЕКСТЕ: НЕСКОЛЬКО СОЦИАЛЬНО-ПСИХОЛОГИЧЕСКИХ КОММЕНТАРИЕВ
}

\author{
И.Б. Бовина, Н.В. Дворянчиков, С.Ю. Гаямова \\ Московский государственный психолого-педагогический университет \\ Сретенка, 29, Москва, Россия, 127051 \\ Л. Дани, М.-А. Эм \\ Университет Экс-Марселя \\ Avenue R. Schuman, 3-29, Aix-en-Provence, France, 13628
}

\begin{abstract}
Цель настоящей статьи заключается в обсуждении некоторых аспектов, связанных с культурным и социальным контекстами здоровья и болезни, в выявлении особенностей, которые влияют на социальные представления о здоровье и болезни у жителей России. Особое внимание уделяется специфике языковой картины мира, отмечается, что русский язык обеспечивает говорящего запасом степеней свободы для того, чтобы он мог избежать ответственности за свои поступки и действия. Анализ понятий «здоровье» и «болезнь» в русском языке, согласно В.В. Колесову и М. Фасмеру, выступает в качестве основы для изучения формирования социальных представлений о здоровье и болезни. В фокусе внимания оказываются социально-экономические и демографические особенности ситуации, в которой порождаются представления, отмечается пренебрежение своим здоровьем как одна из особенностей поведения в отношении здоровья.
\end{abstract}

Ключевые слова: здоровье, болезнь, социальные представления, культурный и социальный контекст, непредсказуемость мира

\section{Благодарности и финансирование:}

Настоящая статья является частью научно-исследовательского проекта, поддержанного РГНФ (16-26-08001 а) и Фондом Дома наук о человеке.

\section{История статьи:}

Поступила в редакцию: 5 декабря 2016

Принята к печати: 17 января 2017

Для цитирования:

Бовина И.Б., Дворянчиков Н.В., Гаямова С.Ю., Дани Л., Эм М.-А. Здоровье и болезнь в русском контексте: несколько социально-психологических комментариев // Вестник РУДН. Серия: Психология и педагогика. 2017. Т. 14. № 1. С. 7-16.

\section{Сведения об авторах:}

Бовина Инна Борисовна - доктор психологических наук, доцент, профессор кафедры клинической и судебной психологии факультета юридической психологии Московского государственного психолого-педагогического университета (Москва, Россия). Контактная информация: e-mail: innabovina@yandex.ru

Дворянчиков Николай Викторович - кандидат психологических наук, доцент, профессор кафедры клинической и судебной психологии факультета юридической психологии Московского государственного психолого-педагогического университета, декан факультета юридической психологии (Москва, Россия). Контактная информация: e-mail: dvorian@ gmail.com 
Гаямова Светлана Юрьевна - кандидат психологических наук, доцент, доцент кафедры юридической психологии и права Московского государственного психолого-педагогического университета (Москва, Россия). Контактная информация: e-mail: sgayamova@ yandex.ru

Дани Лионель - руководитель исследований, профессор, лаборатория социальной психологии университета Экс-ан-Прованса-Марселя (Экс-ан-Прованс, Франция). Контактная информация: e-mail: lionel.dany@univ-amu.fr

Эм Мария-Анастасия - аспирант, лаборатория социальной психологии университета Экс-ан-Прованса-Марселя (Экс-ан-Прованс, Франция). Контактная информация: e-mail: marie-anastasie.aim@univ-amu.fr 